\title{
Revisitando a "Ária (Cantilena)" da Bachianas Brasileiras n. 5 (1938) de Villa-Lobos
}

\author{
Norton Dudeque* \\ Universidade Federal do Paraná
}

\section{Resumo:}

Este artigo discute a contextualização e a música da Ária (Cantilena) da Bachianas Brasileiras n. 5 de Heitor Villa-Lobos. A série das Bachianas Brasileiras geralmente é vista como uma referência à música de Johann Sebastian Bach. Apesar das tentativas de ilustrar de maneira objetiva como estas referências são utilizadas pelo compositor, poucos têm obtido sucesso neste objetivo. $\mathrm{O}$ autor do presente texto toma a idéia de desdobramento motívico elaborada por Arnold Schoenberg como uma técnica analítica que pode elucidar o uso de uma das várias formas que Villa-Lobos utiliza para referenciar a música de Bach.

Palavras-chave: Bachianas Brasileiras; Villa-Lobos; análise musical

* Norton Dudeque é professor do Departamento de Artes da UFPR e tem atuado na área de teoria e análise musical. Norton é autor de Music Theory and Analysis in the Writings of Arnold Schoenberg (1874-1951), publicado pela editora Ashgate (Grã-Bretanha, 2005). 
A referência a obras de compositores do passado como estratégia de desenvolvimento de idéias musicais é comum entre inúmeros compositores do século XX. ${ }^{1}$ Talvez os exemplos mais conhecidos sejam Stravinsky e o neoclassicismo; Schoenberg e a utilização de formas musicais tradicionais, e o reconhecimento teórico da sua herança cultural/musical germânica; e Webern e o estudo acadêmico da música do passado e sua reinterpretação de técnicas composicionais. Villa-Lobos não é exceção, apesar de que várias de suas obras apresentam uma concepção original em termos formais e melódico-harmônicos, representadas, em especial, na série de Choros, em que o compositor brasileiro também utilizou referências à música do passado como uma fonte de inspiração para o desenvolvimento de idéias musicais.

Muito embora haja uma literatura bastante grande sobre a recepção da obra de J. S. Bach, pouco se tem observado a respeito de como compositores têm recebido e percebido a obra de Bach, tanto como uma reflexão teórica quanto como uma influência em suas próprias composições. A influência, as alusões composicionais e estéticas à obra de Bach são parte da preocupação demonstrada por Finscher (1998) ao discutir o papel póstumo de Bach na história da música.

132 Ele reflete sobre a importância de J. S. Bach e sua música abordando aspectos históricos, estéticos, teóricos e de influência de técnica musical. Assim, Finscher relata duas maneiras distintas de falar sobre Bach: a primeira se refere à criação de um Bach super-humano, cosmológico e mitológico; a segunda se refere à prática composicional inspirada na linguagem musical de Bach, à reflexão consciente e racional da sua técnica composicional.

O protagonista da primeira abordagem é Richard Wagner. Segundo Finscher, Wagner considerava a abertura de sua ópera Die Meistersinger como "Bach aplicado" e a terceira cena, no primeiro ato, como uma "continuação de Bach" (p. 6). Essa "romantização" da figura e da música de Bach ocorre durante o

\footnotetext{
1 Parte deste trabalho foi apresentado na Conferência CarMAC, Cardiff Music Analysis Conference, realizada na Escola de Música da Universidade de Cardiff, Reino Unido, entre 4 e 7 de setembro de 2008.
} 
século XIX após a redescoberta da Paixão Segundo São Mateus por Mendelssohn em 1829. Este movimento de retomada ou redescobrimento da música de Bach durante o séc. XIX é descrito de maneira concisa por Blume (1964), que identifica duas tendências principais neste movimento romântico: a primeira caracterizada por uma busca de um paradigma confiável, uma autoridade indiscutível; a segunda, uma tendência de buscar refúgio (ou apoio) na ordem estabelecida da grandiosidade do passado (p. 295). A música e a figura de Bach tornou-se, durante esta época, o epítome necessário para os ideais estéticos destas tendências. Apesar da redescoberta da música vocal e sacra de Bach, foi sua música instrumental que se tornou modelo para uma reinterpretação durante o séc. XIX. Segundo Dahlhaus (1989), esta reinterpretação transmutou as obras de Bach em modelos e paradigmas de "música instrumental pura", a qual os românticos consideravam a essência da música per se, além de criar uma reafirmação de si próprios como herdeiros de uma realidade musical e, de certa maneira, de um ideal estético (p. 30-31). Durante o séc. XIX as referências a obras e à linguagem bachiana são inúmeras. Por exemplo, Beethoven em suas Variações Diabelli Op. 120 faz alusões às Variações Goldberg (vide Kinderman, 1998, p. 81-108). Nesta obra, as referências são perceptíveis nas variações 31 , que se referem diretamente à variação 25 da obra de Bach. Já as variações 32 , uma fuga tripla, seguida de um Tempo di Minuetto (variações 33), também se referem à linguagem bachiana e completam as referências à música de Bach na obra de Beethoven.

Se alusões à obra de Bach podem ser vistas ao longo do século XIX, no seu final, e início do século XX, Max Reger (1873-1916) adquire o papel de maior herdeiro desta romantização da figura de Bach, mesmo que à sombra da obra de Wagner. Reger escreve: Bach "o começo e fim de toda música, Bach pai onipresente, padrinho da música, pai da harmonia". ${ }^{2}$ As referências de Reger à obra de Bach adquirem um aspecto diferenciado do que nos anos de 1920 viria a ser chamado de neoclassicismo. Reger, na visão de Frisch (2001) é o compositor

\footnotetext{
2 "Anfang und Ende aller Musik, Allvater Bach, Musikgottvater, Urvater der Harmonie" (Reger apud Lorenzen, 1982, p. 55).
} 
que mais assimilou a obra de Bach na sua própria, chegando até mesmo a uma identificação “monomaníaca”, psicótica, em termos de auto-afirmação. Frisch, de fato, argumenta que a releitura que Reger faz de Bach é modernamente histórica, ou seja, é imbuída da história referente a Bach. Ainda, Bekker (1919) acrescenta que a arte melódica de Bach poderia mostrar o caminho para uma linguagem musical moderna que não fosse uma mera imitação ou adoção superficial, mas sim uma readaptação e reconhecimento de elementos estilísticos de uma arte antiga. Bekker não está se referindo ao neoclassicismo, mas sim ao que Frisch chama de modernismo historicista (2001, p. 298-299). ${ }^{3}$

A segunda maneira de se falar de Bach, de acordo com Finscher, se refere à prática composicional (e analítica) sobre a música de Bach. Inicialmente nos referimos a Schoenberg, quem declarava abertamente o seu aprendizado composicional, autodidata, baseado em Mozart e Bach. Deste último, Schoenberg (1975) dizia ter herdado quatro idéias principais: 1. o pensamento contrapontístico; 2. a arte de desenvolver tudo em uma obra a partir de uma entidade única; 3. o desenvolvimento de configurações uma das outras; e 4. a libertação da métrica tradicional, “do tempo forte do compasso" (p. 173). Ainda neste viés, Besseler (1926), durante os anos da República de Weimar, categoriza dois tipos fundamentais de música: uma música autônoma, isto é, uma música para ser ouvida e apreciada esteticamente, eigenständing Musik, e uma música de caráter mais utilitário e vernacular, Gebrauchsmusik ou umgangsmäßige Musik. Posteriormente Besseler mudou esta denominação para Darbietungsmusik (música de apresentação) e para Umgangsmusik. Nesta segunda categoria incluía-se aí a música popular (inclusive o Jazz) e a música do passado. Em 1921. Paul Hindemith passou a considerar a música de Bach como um modelo para Umgangsmusik, e não para a Darbietungsmusik. A tendência estética, então, que se consolidou na década de 1920 pode ser percebida no slogan "zurück zu Bach" (retorno a Bach) ou em outras palavras "zurück zu Umgangsmusik". Esta

\footnotetext{
${ }^{3}$ Entre as várias obras de Reger que fazem alusão a Bach, são representativas a Phantasie und Fuge über den Namen B-A-C-H Op. 46 para órgão, Suíte em Mi menor Op. 16 para órgão, Corale-Preludes baseados em corais para órgão de Bach etc. (Vide também Bekker, 1923, p. 100-101).
} 
tendência se concretiza na obra de Hindemith quando, em 1924, ele compõe Kammermusikn. 2, a qual inaugura uma abordagem neobarroca na sua música. Cada uma das sete obras que compõe o ciclo designado como Kammermusik, com exceção da primeira, é moldada como um concerto para uma variedade de instrumentos solista(s) e orquestra com diferentes tamanhos e constituições. MacDonald refere-se a estas composições como "um tipo equivalente no século XX aos Concertos Brandenburgo de J. S. Bach" (apud Hinton, 1998, p. 139). Ainda Hindemith realiza em Unterweisung im Tonsatz (1935-37) uma análise da Invenção a 3 vozes em Fá menor, de Bach, ilustrando a flutuação harmônica de acordo com a teoria desenvolvida (vide Hindemith, 1942, p. 207-209).

A tendência do neobarroco de Hindemith também era sentida em Paris, onde Stravinsky tornava o slogan "retour à Bach" ouvido em uma afirmação estética. Entre 1923 e 1925, Stravinsky compõe o Octuor (1923), Sonate para piano (1924) e Sérénade en la (1925), obras em que há uma renúncia do caráter nacionalista em favor de um léxico altamente alusivo a Bach: "a fonte de valores musicais universais". Em poucos anos, o slogan e a tendência de "retour à Bach" tornou-se predominante entre os músicos que freqüentavam os círculos musicais de Paris da época (Taruskin, 1996, p. 1607).

Finalmente, no ponto de vista de Dahlhaus (1982), que em seu Grundlagen der Musikgeschichte reflete sobre o historicismo musical no século XIX, "tradição" e "restauração" são duas tendências dialéticas que norteiam a idéia de progresso no século. A primeira tem uma ligação direta com o passado e pressupõe uma continuidade sem arestas, e é freqüentemente associada a uma corrente ininterrupta. A segunda, restauração, é uma tentativa de renovar o contato com uma tradição que foi interrompida. Assim, durante o século XIX, as músicas de Mozart e Beethoven pertenciam a uma tradição viva, enquanto que a música de Bach, distante no tempo, era objeto de restauração (p. 67-70).

Muito embora as Bachianas Brasileiras datem do período de 1930 a 1945, portanto bastante posterior ao surgimento do neoclassicismo na Europa continental, esta tendência internacionalista pode ser observada na incorporação que Villa-Lobos faz da mitificação da figura de Bach como "fonte folclórica 
universal”. Em uma curiosa auto-avaliação, escrita em 1947, da sua própria percepção sobre a importância universal da música de Bach, Villa-Lobos escreveu:

Bachianas Brasileiras - título de um gênero de composição musical criado de 1930 a 1945 para homenagear o grande gênio John [sic] Sebastian Bach. As Bachianas Brasileiras, em Bach, considerado pelo autor como fonte folclórica universal, rica e profunda, com todos os materiais sonoros populares de todos os países, intermediária de todos os povos. Para VillaLobos, a música de Bach vem do infinito astral para se infiltrar na terra como música folclórica, e o fenômeno cósmico se reproduz nos solos, subdividindo-se nas várias partes do globo terrestre, com tendência a universalizar-se (Museu Villa-Lobos, 1972, p. 187).

As observações intuitivas (e um tanto delirantes) de Villa-Lobos sobre a universalidade de Bach demonstram a fascinação desta música sobre ele. Os biógrafos de Villa-Lobos mencionam que sua tia Zizinha executava Prelúdios e Fugas do Cravo Bem Temperado durante a sua infância. Villa-Lobos tem uma posição ambígua em relação às questões discutidas acima. Se por um lado, ele romantiza e fantasia sobre a figura de Bach como "fonte folclórica universal" e fonte de todos os "materiais sonoros populares de todos os países", na prática ele articula estruturas musicais de maneira a aludir à música de Bach, de maneira 136 bastante variada, e que se estende desde alusões ingênuas até releituras sofisticadas de estruturas bachianas. A atração de Villa-Lobos pela música de Bach pode ter se tornado um argumento para prover as idéias de como utilizar o material musical para a série das Bachianas Brasileiras. No entanto, Béhague (1994) observa que o que Villa-Lobos percebeu de forma intuitiva foi certas afinidades entre texturas contrapontísticas e procedimentos rítmicos em Bach com certos aspectos da música popular brasileira (p. 105-106).

Nóbrega (1969) sintetiza a percepção de Villa-Lobos sobre as coincidências entre a música de J. S. Bach e a música popular brasileira da sua época. Nóbrega descreve: "Trata-se da descoberta da similitude de procedimentos melódicos, harmônicos e contrapontísticos entre certas modalidades da música popular instrumental brasileira e a música de Bach. Um 'ovo de Colombo'” (p. 17). Ademais, a tentativa de Nóbrega (1976) de comparar 
ou de aproximar a música de Bach à música popular brasileira, fazendo breves paralelos entre obras de Bach e modinhas e chorinhos, por vezes causa surpresa (p. 12-16); ou como Kiefer (1986) se refere a esta proximidade, "a semelhança chega a ser às vezes impressionante" (p. 114). No entanto, as comparações que faz Nóbrega parecem não se aproximar da intenção real de Villa-Lobos: a de realizar uma releitura das características da música de Bach de acordo com suas próprias convicções composicionais, ou adaptando a terminologia de Dahlhaus, a de realizar um ato de restauração de uma tradição pertencente, segundo VillaLobos, a toda à humanidade.

A restauração pretendida por Villa-Lobos também é herdada da música romântica brasileira: uma tradição de composições que fazem alusões à música do passado, em especial à música barroca. A Suíte Antiga Op. 25 de Leopoldo Miguéz, escrita para orquestra em 1892 e dedicada a Alberto Nepomuceno, tem como movimentos I. Prelude, II. Sarabande, III. Gavotte, IV. Air et Double, e V. Gingue [sic] (Corrêa, 2005, p. 60). Já a Suíte Antiga Op. 11 de Alberto Nepomuceno, escrita originalmente para piano em 1893 e transcrita para orquestra de cordas em 1894, tem como seus movimentos: I. Prélude, II. Air, III. Minueto, IV. Rigaudon. A obra de Nepomuceno, que parece ter a característica de um exercício estilístico à maneira de Bach, serviu como obra de conclusão de curso em 1894, no Sternsches Konservatorium, em Berlim (Corrêa, 1985, p. 24). ${ }^{4}$

A série das nove Bachianas Brasileiras reflete em muitos aspectos a adoção de referências à música de Bach. Por exemplo, muitas destas obras são estruturas na forma de suíte, contando entre seus movimentos alusões a danças de suíte barroca. Ilustrativas destas alusões são as ambiciosas Bachianas Brasileiras n. 7. composta em 1942, e a Bachianas n. 8, de 1944. A primeira é uma suíte para orquestra em quatro movimentos, contendo Prelúdio, Giga, Tocata e Fuga. A segunda tem como seus movimentos Prelúdio, Ária, Tocata e Fuga. Ademais, o par de movimentos Prelúdio e Fuga também são aludidos nesta série de obras. Por exemplo, a Bachianas Brasileiras n. 1, de 1930, tem como seus segundo e

\footnotetext{
${ }^{4}$ Rodolfo Coelho escreve sobre a Suíte Antiga Op. 11 de Nepomuceno neste número de Música em Perspectiva.
} 
terceiro movimentos, respectivamente, um Prelúdio e uma Fuga, esta última designada como Conversa pelo compositor. Já a última obra da série, originalmente para orquestra de vozes e datada de 1945, é estruturada em dois movimentos: Prelúdio e Fuga.

Na época em que Villa-Lobos compôs sua série de Bachianas Brasileiras, ele estava envolvido em projetos de transcrição de obras de Bach. Em 1938, ele arranjou para orquestra a Fantasia e Fuga n. 6 para órgão; e entre 1932 e 1937. ele arranjou vários Prelúdios e Fugas do Cravo Bem Temperado para coro misto. ${ }^{5}$ A maioria destes arranjos tinha como objetivo as práticas orfeônicas iniciadas em 1931, ano em que Villa-Lobos assumiu a direção da SEMA (Superintendência de Educação Musical e Artística). Ademais, a criação do "Curso de Pedagogia de Música e Canto Orfeônico" e o "Orfeão dos Professores do Distrito Federal”, em 1932. propiciou o meio para divulgar e executar estes arranjos, ou melhor, arranjos de uma música imbuída de valores artísticos, "folclóricos", éticos e morais de escopo universal (Museu Villa-Lobos, 1972, p. 72-73, 78). As Bachianas Brasileiras ainda podem ser vistas como parte de um programa de educação musical do povo brasileiro imposto por Villa-Lobos e Getúlio Vargas. Ou como Arcanjo Jr. (2007, p. 69) comenta:

\begin{abstract}
Para Villa-Lobos, o público brasileiro, “inculto" musicalmente, não estava preparado para compreender um compositor tão "erudito", "civilizado" e complexo quanto Bach. Desta forma, na sua concepção, a música bachiana poderia ser um instrumento pedagógico que, misturado à tradição musical "primitiva" do Brasil, por meio de "pequenas dosagens" como nas Bachianas Brasileiras, poderia produzir o efeito desejado para uma cultura "em desenvolvimento." 6
\end{abstract}

Assim, o contexto onde se cria uma imagem mitológica, cósmica de Bach, o contexto internacional de tendências composicionais e estéticas e até mesmo uma

\footnotetext{
5 Prelúdios n. 4 (1934), 8 (1932), 14 (1937), 22 (1932) e as Fugas 1, 5, 8, 21, todas arranjadas em 1932.

${ }^{6}$ Para uma visão geral destas questões, vide Arcanjo Jr., O ritmo da mistura e o compasso da História (2007). Wisnik também discute a ação de Villa-Lobos junto ao Estado Novo, em O Orfeão do Estado Novo/Esse Coqueiro que dá Coco (2001).
} 
agenda educacional se interpenetram para formar a contextualização das Bachianas Brasileiras.

Uma característica freqüentemente observada na música de Bach diz respeito a uma técnica utilizada em que os mesmos elementos constituintes são reorganizados e reordenados. Uma ilustração simples deste tipo de procedimento técnico/composicional pode ser observada no Prelúdio n. 5 do primeiro livro do Cravo Bem Temperado. O Exemplo 1 ilustra os dois primeiros compassos da obra. Aqui se observa que a repetição motívica (motivo a) ocorre de maneira quase sempre variada e reordenada. Por exemplo, entre o motivo inicial a e al ocorre uma variação por reordenamento de notas e que produz uma inversão do sentido ascendente inicial do motivo. Já o motivo a2 retorna a um nível de reconhecimento mais próximo ao motivo inicial $a$, mas ao mesmo tempo gera variação e produz os motivos subseqüentes $a 3$ e a4. Somente o motivo $b$ parece ser distinto pela sua terminação, mas sua relação com o motivo inicial também é clara.

\section{Exemplo 1}

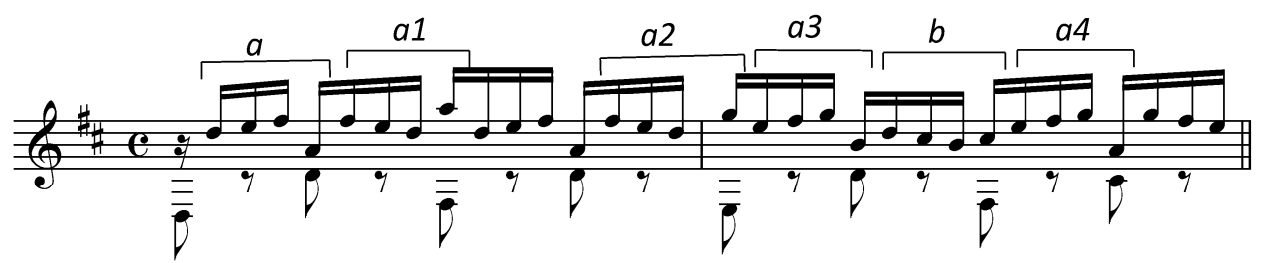

Um exemplo mais sofisticado deste tipo de reordenamento e reorganização temática pode ser observado no Minueto I da Partita I// para violino solo de Bach (vide Exemplo 2a). O período inicial da peça apresenta uma melodia bastante marcada pela utilização de um motivo de notas repetidas em semínimas (motivo a) e um motivo de bordadura (motivo b). Estes elementos motívicos são simples, 
mas de maneira impressionante são trabalhados no período inicial e acabam por permear a peça na sua totalidade. O Exemplo 2a ilustra o período inicial (compassos 1-8); Exemplo $2 \mathrm{~b}$ mostra os motivos iniciais $a$ e $b$ no primeiro compasso. Já no segundo compasso (Exemplo 2c) ocorre uma reordenação do motivo $b$, que é modificado para uma bordadura dupla sobre a nota mi (motivos $b 1$ e $b 2$ ). No compasso 4 (Exemplo 2d), o motivo a é reapresentado na forma de notas recorrentes no tempo forte de cada grupo de duas colcheias; já o motivo $b$ está inserido nas bordaduras inferiores e superiores marcadas com um colchete (motivos b3 e b4). Finalmente, no compasso 5 também ocorre uma reordenação desta configuração motívica básica. De maneira mais sutil, o motivo b5 é apresentado entre notas da bordadura inferior (sol-fá-sol) e como bordadura superior no motivo b6 (sol-lá-sol) (vide Exemplo 2e).

\section{Exemplo 2}
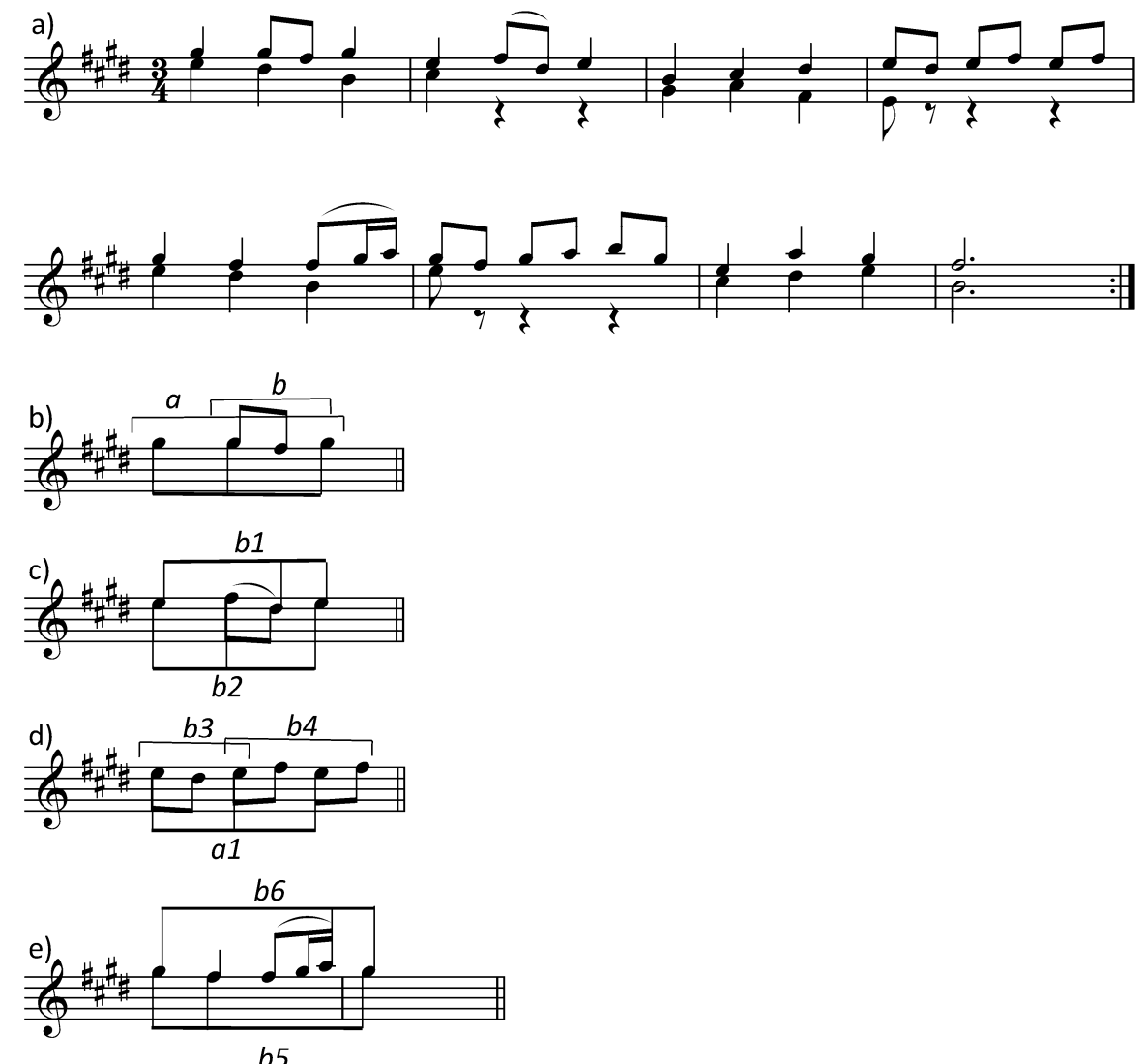

b5 
O efeito resultante é de uma melodia extremamente coesa e fluente, muito embora os compassos 3 e 7 , com predominância de semínimas, interrompam a fluência da melodia do minueto.

Estas observações a respeito da escrita motívica de Bach tomam forma teórica nas observações de Schoenberg (1975) sobre música contrapontística. Para ele, a música de Bach é caracterizada por um processo motívico de "desdobramento" do material motívico básico. Este tipo de técnica composicional, característica, segundo Schoenberg, de um estilo composicional contrapontístico, é consumada pelo procedimento no qual "uma configuração ou combinação básica tomada à parte e reagrupada em ordem diversa contém tudo que poderá gerar uma nova sonoridade posteriormente àquela já apresentada na configuração original." (p. 397). Ademais, Schoenberg (1995, p. 400) também aborda desdobramento como um método para composições nas quais

um número de notas está em uma relação mútua de sucessão e simultaneidade (contrapostas), de maneira que todas as configurações que aparecem no decorrer da obra já estão contidas, formadas ou apresentadas nesta Grundgestalt, ou são parcialmente determinadas por esta possibilidade. A obra resultante simplesmente se "desenrola" como um filme, quadro por quadro, gestalt por gestalt, e até mesmo a seqüência de eventos aqui é lógica e quase que completamente provida aqui.

A distinção que Schoenberg faz entre a música homofônica e contrapontística ilustra sua percepção de diferentes técnicas de composição musical. Assim, para a música em estilo homofônico-melódico, Schoenberg (1975, p. 397) escreve que esta

música com um tema principal, acompanhado de e baseado na harmonia, produz seu material por variação progressiva. Isto significa que, por um lado, variação das características de uma unidade básica produz todas as formulações as quais provêm fluência, contraste, variedade, lógica e unidade; e por outro lado, provêm diferenciação de caráter, humor, expressão, e toda distinção necessária - elaborando, assim, a idéia da obra. 
Apesar da distinção observada nos dois tipos de procedimento composicional (desdobramento e variação progressiva), Schoenberg ainda afirma que J. S. Bach foi capaz de praticar as duas técnicas em determinado momento de sua carreira composicional (p. 118).

Um passo adiante nesta linha de pensamento seria um estilo de composição musical que privilegiasse um processo contínuo de desenvolvimento do material musical, ou seja, "prosa musical". Como ponto de partida de sua argumentação, Schoenberg observa a formação de estruturas e frases assimétricas nas obras de compositores do passado. Em particular, Schoenberg considera Mozart e Brahms como os compositores mais proeminentes neste aspecto, e de quem esta idéia pode ter se originado. Assim, para Schoenberg, prosa musical é relacionada ao desenvolvimento direto e contínuo de idéias musicais. Ao tentar definir tal procedimento, Schoenberg declara: "prosa musical deveria ser uma apresentação de idéias direta e objetiva, sem meros preenchimentos e repetições sem sentido." (p. 414-415).

Resumindo, a idéia de diferentes técnicas composicionais abordada por Schoenberg $(1995 ; 1975)$ pode ser entendida como uma tentativa de explicitar como um compositor adquire uma fluência na criação de suas obras; isto é, devese considerar que são técnicas composicionais que propiciam maneiras de compor música plenamente. A seguir vamos observar como a melodia da Cantilena, da Bachianas Brasileiras $n$. 5, é um exemplo desta maneira de compor música.

\section{2}

A obra abordada neste artigo é um tipo de ária, famosa por sua bela melodia extremamente fluente e pela instrumentação original de Villa-Lobos (soprano e conjunto de violoncelos). A Ária (Cantilena) foi composta em 1938 e tem uma forma ternária A-B-A'. O segundo movimento da obra, Dansa (Martelo), com texto de Manuel Bandeira, foi acrescentado em 1945. A Cantilena, que é o objeto deste estudo, faz referências bastante claras à linguagem musical de Bach e à música popular brasileira da época em que foi composta. O comentário de 
Nóbrega sobre as qualidades da Bachianas n. 5 expressa de maneira contundente a percepção da fluência desta melodia. Nóbrega (1969, p. 18) comenta:

Villa-Lobos grafou essa melodia numa sucessão caprichosa de compassos alternados. Entretanto, o que à primeira vista parece rebuscamento e preciosismo flui maravilhosamente. Nenhum recurso de impressionar o leitor ou o ouvinte. Estudioso apaixonado da música popular brasileira, soube o mestre captar as tenutas e os "rubati", as manhas e maciezas com que os intérpretes populares executam seu repertório, com alterações aleatórias de agógica que freqüentemente implicam numa revalorização métrica. Por isso mesmo é que, a despeito da irregularidade métrica aparente, a Ária das Bachianas Brasileiras n. 5 nos soa tão fluente.

A melodia se desenvolve de maneira a criar uma impressão de fluência, de uma melodia infinita. O Exemplo 3 ilustra a melodia e as respectivas frases indicadas pelas ligaduras de expressão do compositor.

\section{Exemplo 3}

Frase 1

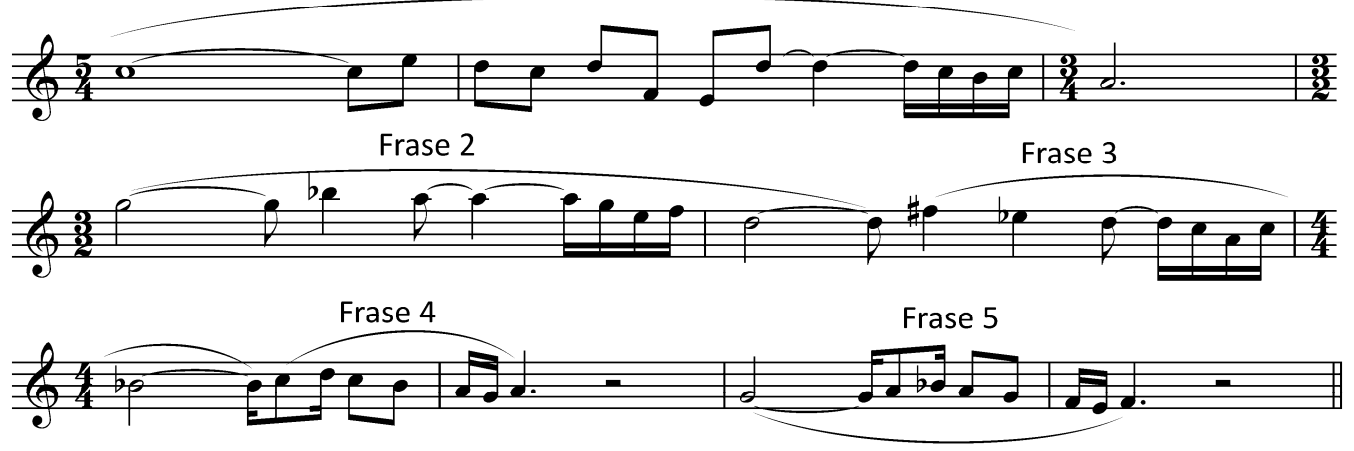

\section{Elementos motívicos da melodia}

O Exemplo 4a (compassos 3-5) ilustra a primeira frase e seus principais elementos motívicos. Motivo a compreende uma terça ascendente (dó-mi), motivo $b$, uma segunda descendente (mi-ré), motivo $c$ compreende ambos os motivos $a$ e $b$, e motivo $d$ é caracterizado pelas semicolcheias e pelo contorno melódico de terminação de frase da seqüência de notas dó-si-dó-lá. É notável que 
no compasso 4 não haja designação de motivos, exceção ao motivo $d$. A razão pela qual isto ocorre é que entre os segundo e quarto tempos deste compasso ocorre uma mera prolongação da harmonia de dominante, primeiramente como vii $^{77}$, do segundo ao quarto tempo do compasso, e depois como $\mathrm{V}^{13 / 7}$ no quinto tempo. Isto é ilustrado nos Exemplos 4b e 4c. Partindo deste raciocínio, podemos então reduzir a frase a uma estrutura descendente apoiada pela progressão harmônica i- $\mathrm{V}^{13 / 7}$-i e que define o motivo e (linha descendente de dó-(ré)-si-lá).

\section{Exemplo 4}
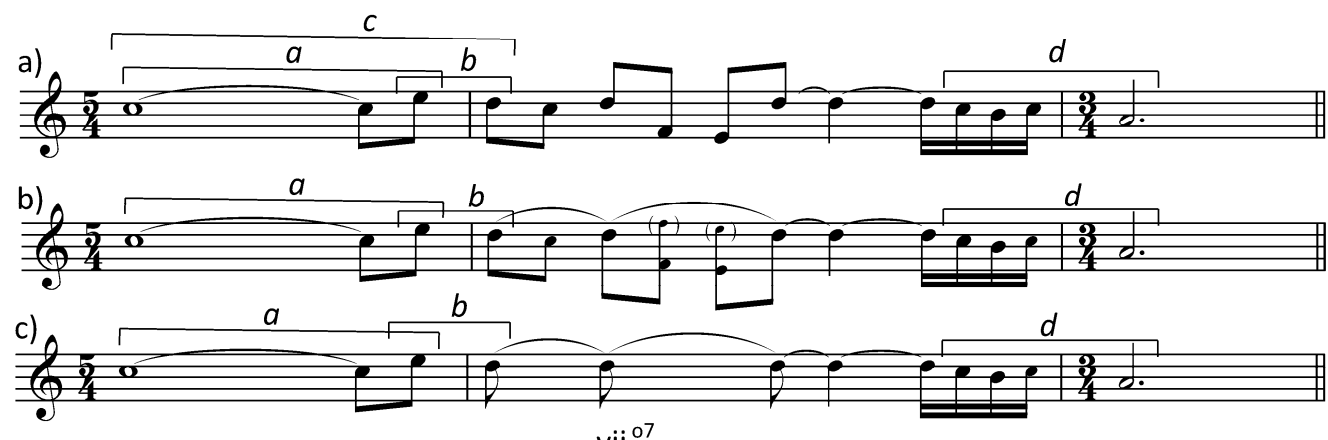

vii ${ }^{07}$

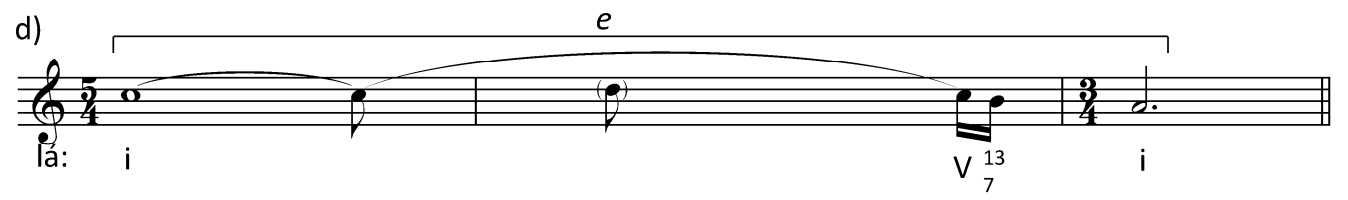

\section{A reordenação dos elementos motívicos da melodia}

As frases subseqüentes são construídas a partir da reordenação destes elementos motívicos, como mostrado no Exemplo 5. Primeiramente, o Exemplo 5 a mostra a primeira frase como modelo de onde serão derivadas outras frases. 0 Exemplo 5b ilustra a segunda frase e a primeira reordenação e modificação: motivo al é modificado para uma terça menor (sol-sib), motivo b1 (sib-lá), motivo cl abarca motivos a 1 e b1, e motivo $d 1$ apresenta a variação do motivo relacionado $d$. Além disso, a frase é comprimida, em dois compassos, em 3/2. 0 Exemplo 5 c mostra a terceira frase, onde se relacionam os motivos a2 e c2 
(indicados com os colchetes pontilhados) pela justaposição das frases 2 e 3 . No entanto, a relação dos motivos b2 e $d 2$ com os motivos correspondentes da primeira frase é clara. Além disso, é necessário observar que a nota final da frase 2 é a inicial da frase 3, ocasionando assim uma justaposição de frases e garantindo a continuidade na melodia.

\section{Exemplo 5}

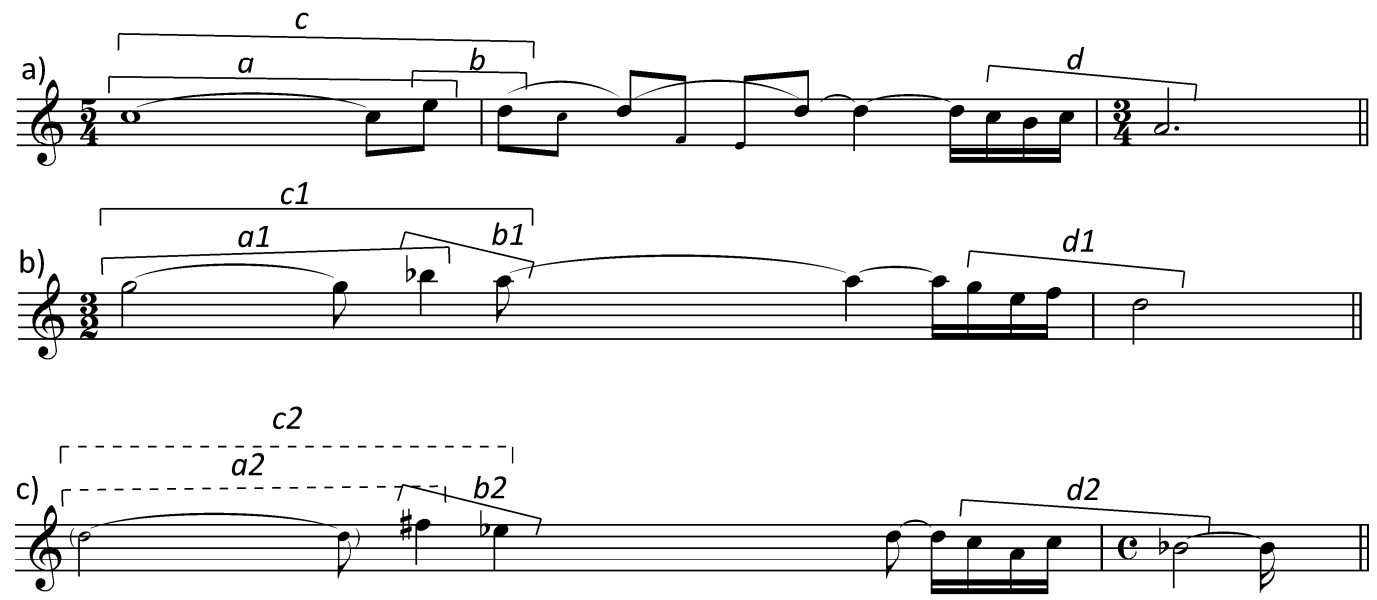

Este tipo de reordenação e desenvolvimento continua nas frases 4 e 5. O Exemplo 6a mostra a conexão entre as frases subseqüentes com a frase 1. A frase 4 começa com uma justaposição da nota sib como final da frase anterior e início da frase 4 , muito embora a indicação de Villa-Lobos para esta frase seja a nota dó seguinte. Finalmente, a frase 5 apresenta todos os elementos da frase precedente de maneira direta e objetiva (vide Exemplo 6b).

\section{Exemplo 6}
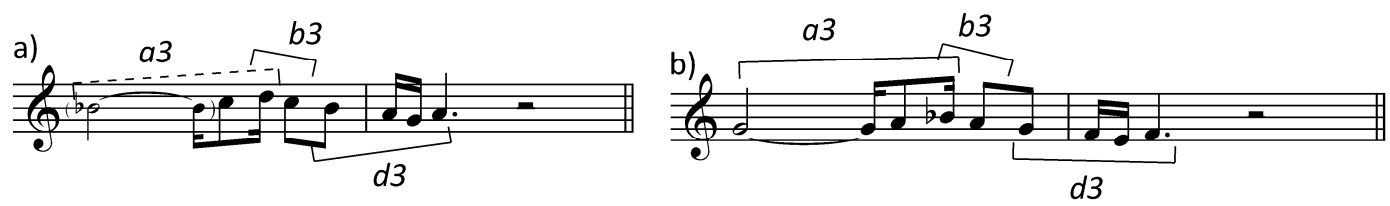
A relação dos elementos motívicos de superfície bastariam para o entendimento da articulação desta melodia e de um estilo melódico de desdobramento motívico. No entanto, estruturas em um plano de fundo estão presentes e também relacionam as frases, e até mesmo as seções da obra - em particular, o motivo e que tem função articulatória de fundo em todas as frases, cada qual com sua própria versão. A primeira versão, ilustrada no Exemplo 7a, inclui a linha descendente dó-si-lá, que representa o contorno melódico geral da frase 1. A segunda versão (Exemplo 7b), a linha sol-fá-ré, caracteriza a frase 2. Ainda é importante observar que esta versão da linha descendente de superfície incluiria a nota mi entre fá e ré, completando, assim, a linha descendente por graus conjuntos (vide Exemplo 5b). No Exemplo 7c, a linha descendente é fá\#-rédó-sib. O Exemplo 7d ilustra a linha descendente da frase 4, que é composta das notas dó-sib-lá. Finalmente, no Exemplo 7e (motivo e4) a linha descendente é abreviada para um par de notas: sol-fá.

\section{Exemplo 7a-e}
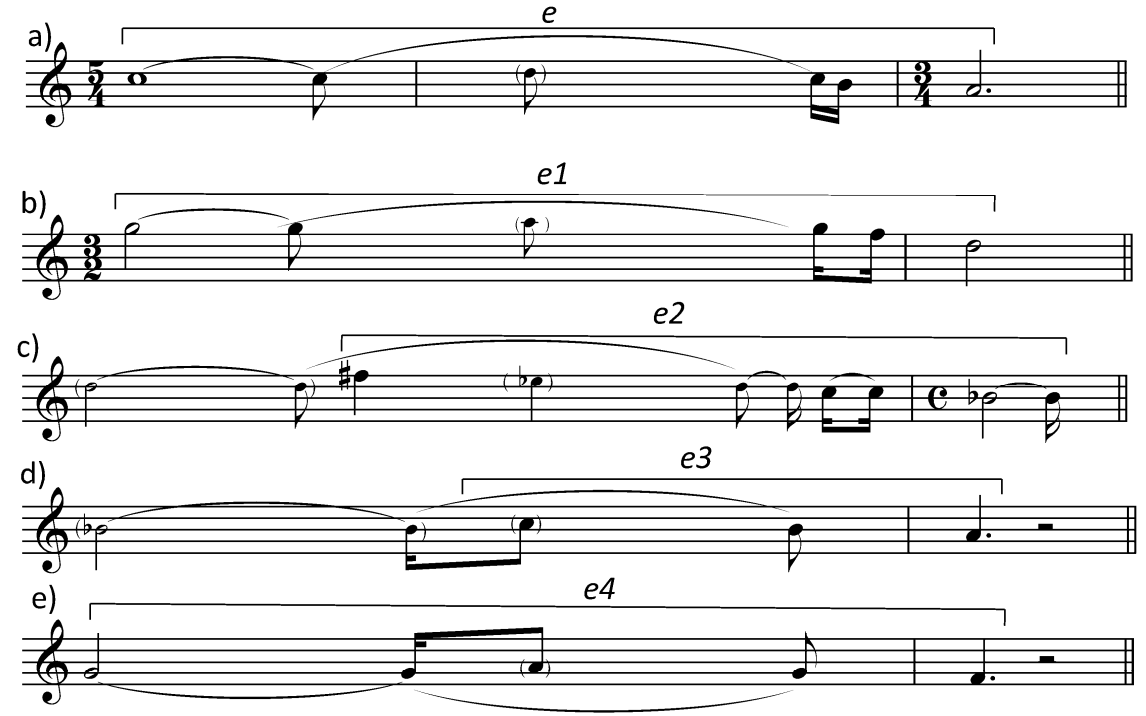

A Cantilena é formalmente estruturada em três seções: uma seção inicial $A$, uma seção central contrastante $B$, e uma seção de recapitulação $A^{\prime}$. A seção central de 
caráter aproximado a um recitativo apresenta texto de Ruth Corrêa, o qual é disposto silabicamente. Esta seção se relaciona de maneira direta à linha descendente das frases iniciais da seção A discutidas acima. De maneira notável, o compositor constrói uma linha melódica descendente, pontuada por arpejos ascendentes, e caracterizados pela apresentação motívica que remete ao motivo $d$ da seção inicial. A linha geral inicial nesta seção B é mi-ré-dó-si-lá\#-lá-sol\#, que gradualmente conduz à dominante de Lá menor e a uma apresentação do motivo $d 4$, utilizado na sua função articuladora usual, isto é, a de conclusão de frases. O Exemplo 8 ilustra a passagem.

\section{Exemplo 8}
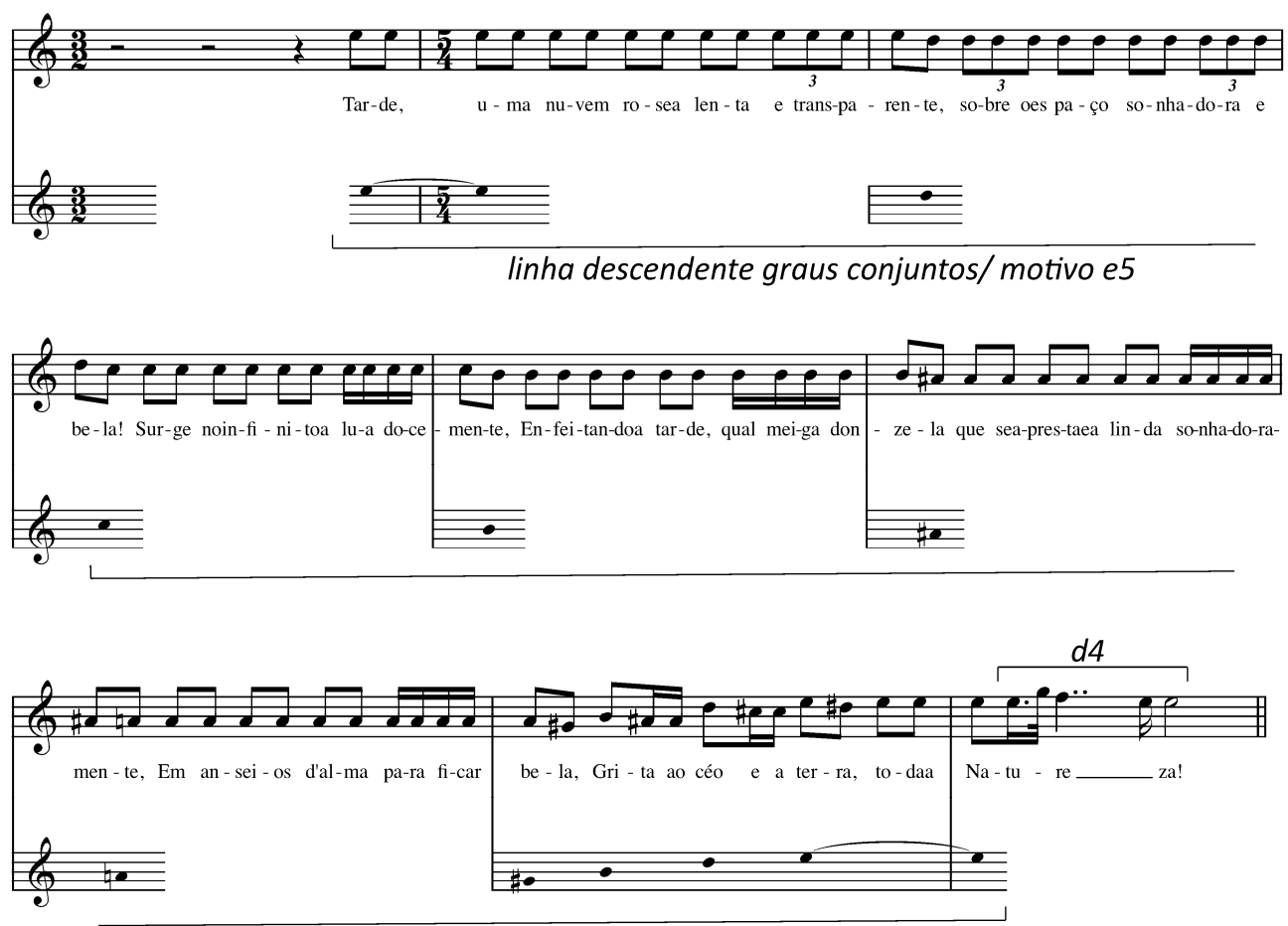

Ainda é importante considerar como o parâmetro harmônico contribui para a continuidade das frases da primeira seção da obra. A continuidade se dá através da harmonização com dominantes que conectam continuamente frase para frase. A Tabela 1 ilustra as notas iniciais e finais de cada frase e sua 
harmonização. A tonalidade instável, sempre cambiante, se soma ao trabalho motívico de reordenação dos elementos para produzir a concatenação fluente desta melodia excepcional. As progressões harmônicas iniciam na tônica Lá menor, passam para Ré maior, Sol menor, Fá maior e Ré menor. Em algumas circunstâncias, a nota que termina uma frase antecipa a harmonia de dominante da próxima frase, produzindo assim, a continuidade desejada. Por exemplo, a primeira frase que tem como nota inicial dó, harmonizada com a tônica (i) de Lá menor, e final lá, esta harmonizada como tônica de Lá menor (i) e posteriormente com a dominante de Ré menor (ré: V), portanto apresenta uma antecipação da harmonia de dominante da próxima frase. Na segunda frase, em Ré maior, a primeira nota, sol, é harmonizada com o acorde de dominante. Já a última nota da frase, ré, é harmonizada como tônica; no entanto, neste momento a função harmônica muda para dominante de Sol menor, e assim, conecta-se com a próxima frase. Este trabalho harmônico é ilustrado na Tabela 1.

Tabela 1

\begin{tabular}{|c|c|c|c|c|}
\hline Frases & $\begin{array}{c}\text { Notas } \\
\text { iniciais }\end{array}$ & Harmonia & $\begin{array}{c}\text { Notas } \\
\text { finais }\end{array}$ & Harmonia \\
\hline Frase 1 & Dó & (lá: i) & Lá & (lá: i) (Ré: V) \\
\hline Frase 2 & Sol & (Ré: V) & Ré & (Ré: I) \\
\hline Frase 3 & Fá\# & (sol: V) & Sib & (sol: i) \\
\hline Frase 4 & Dó & $($ Fá: V) & Lá & (Fá: I) \\
\hline Frase 5 & Sol & (ré: vii $\left.{ }^{7}-\mathrm{V}\right)$ & Fá & (ré: i) \\
\hline
\end{tabular}

O Exemplo 9 ilustra em notação musical a tabela anterior e acrescenta a finalização motívica de cada frase. 


\section{Exemplo 9}

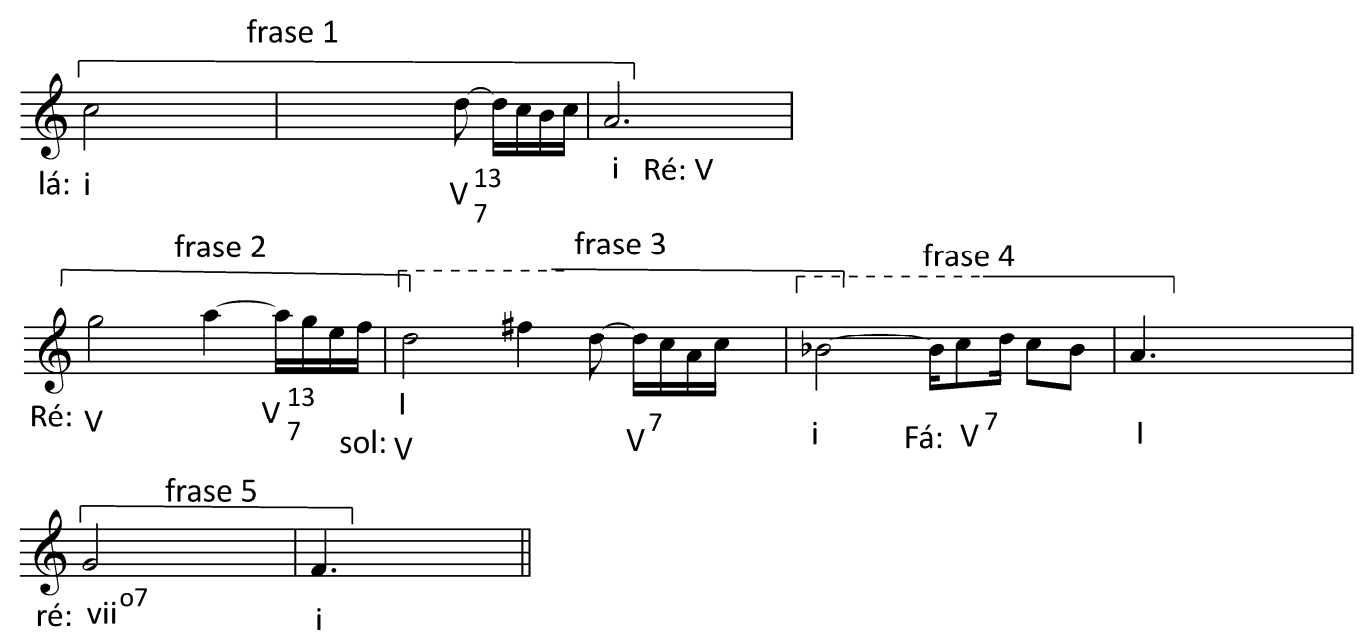

O período resultante da seção inicial é, portanto, coeso, tanto em seu aspecto motívico quanto harmônico. No entanto, as frases são assimétricas, o que contribui para uma sensação auditiva de fluidez e de improvisação melódica. Se tomarmos a semínima como unidade para cada uma das frases, teremos uma assimetria resultante como segue:

Frase 1: 13 semínimas;

Frase 2: 8 semínimas +1 colcheia;

Frase 3: 5 semínimas +1 colcheia +1 semicolcheia;

Frase 4: 3 semínimas +1 colcheia +1 semicolcheia;

Frase 5: 6 semínimas.

Em resumo, a reordenação dos elementos motívicos é de reconhecimento imediato e tem uma importante função na percepção da fluência melódica. Ademais, a harmonização usada pelo compositor conecta frase a frase e resulta em um efeito de conexão e, ao mesmo tempo, fluência melódica. Finalmente, as frases que se conectam por justaposição estão no meio do período e provêm uma grande congruência na conexão da estrutura inteira. 


\section{Afinidades Bachianas}

O uso de tonalidade tradicional por Villa-Lobos nos remete - desde uma aproximação da sua linguagem musical anteriormente caracterizada por uma tonalidade moderna, em obras como a série de Choros - a uma tradição de música tonal e conseqüentemente à música de Bach. Em muitas das obras do ciclo de Bachianas, progressões que compreendem o ciclo de quintas estão presentes. Na Cantilena, Villa-Lobos utiliza esse tipo de progressão harmônica de forma enfática, tanto na conexão de frases musicais como observado anteriormente, quanto na realização de seqüências propriamente ditas. No Exemplo 10 é mostrada uma seqüência utilizando o círculo de quintas diatônicas completo, enfatizado pela linha do baixo: ré-sol-dó-fá-si-mi-lá-ré (incluindo aí o trítono entre fá-si).

\section{Exemplo 10}

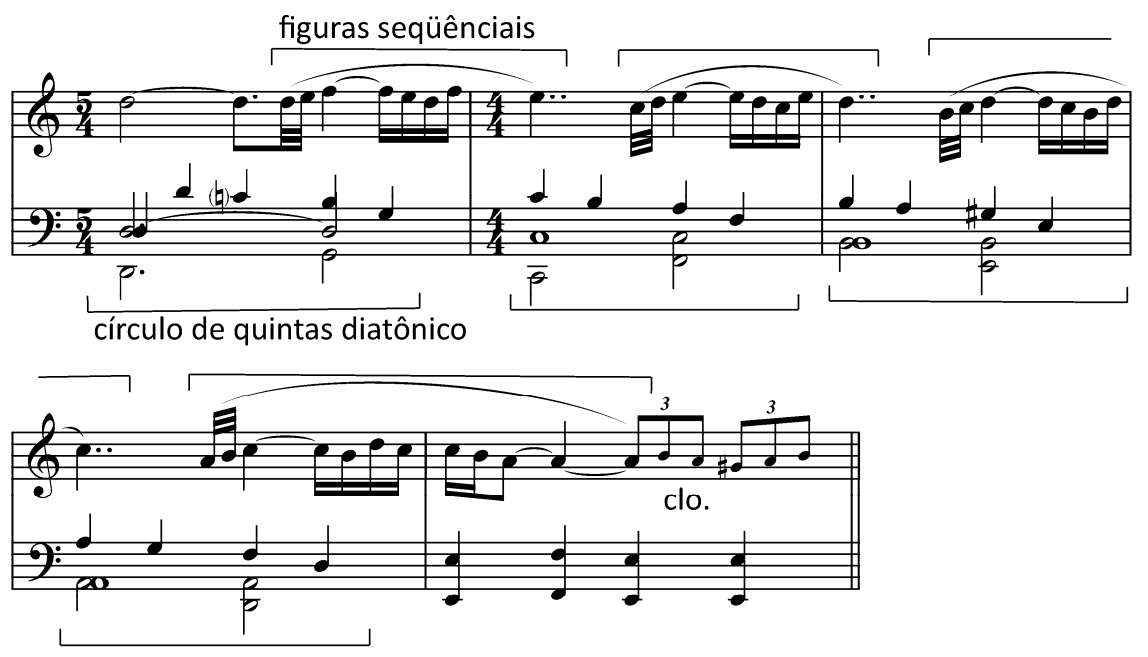

As afinidades entre as texturas contrapontísticas e procedimentos rítmicos na música de Bach com alguns aspectos da música popular brasileira que Béhague comenta podem ser ilustradas na textura contrapontística do acompanhamento do conjunto de cellos. As figurações rítmicas são compostas principalmente por arpejos, fragmentos de escalas, acordes repetidos e sincopados e por uma linha 
de baixo caminhante no cello III. Um exercício ilustrativo dos procedimentos contrapontísticos de Villa-Lobos pode ser a redução da passagem contida no Exemplo 11a em um simples exercício de contraponto a 4 vozes (Exemplo 11b). Apesar das particularidades da escrita contrapontística de Villa-Lobos, a textura geral se aproxima a de um contraponto tradicional.

\section{Exemplo 11a}

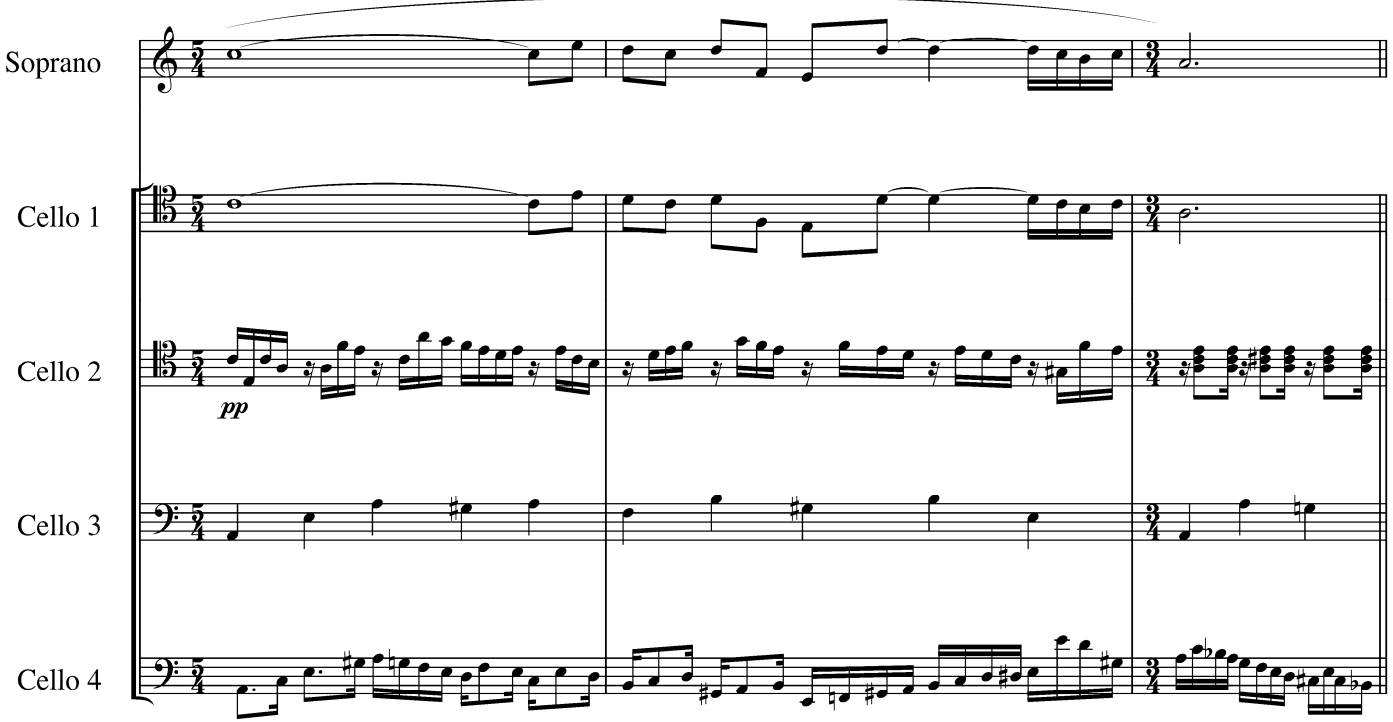

\section{Exemplo 11b}

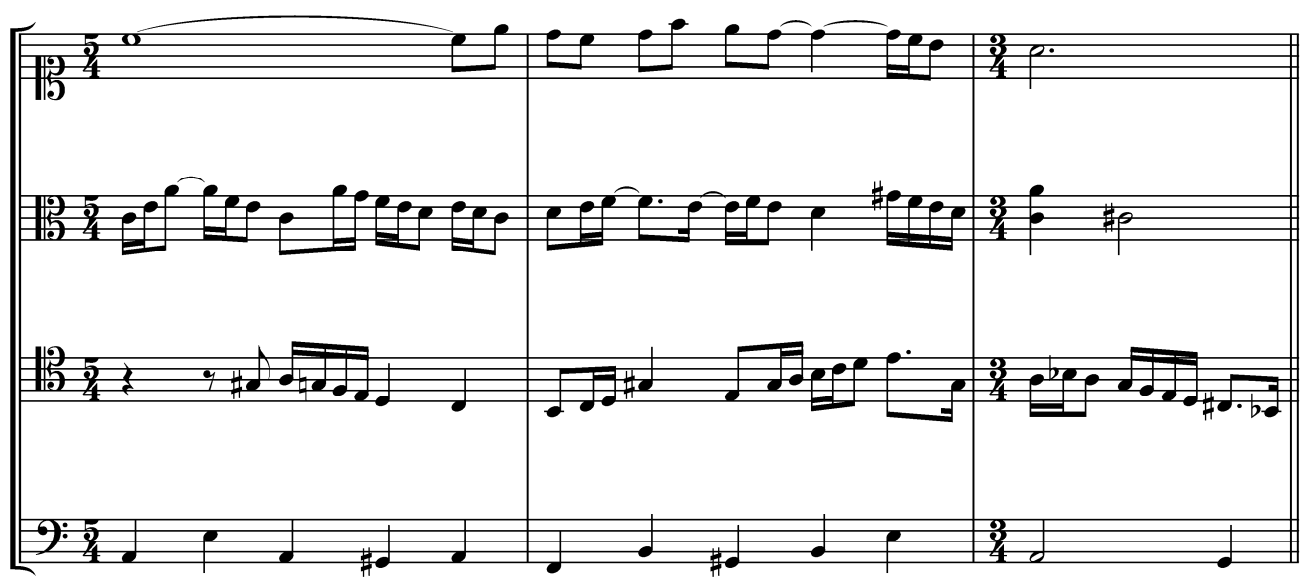


Deste exercício de contraponto baseado nos compassos 3-5 da obra de Villa-Lobos, pode-se extrair uma combinação contrapontística básica e que serve de fundamento para a obra (vide Exemplo 12a). A partir desta Grundgestalt, ou forma básica, várias combinações podem ser abstraídas e podem ilustrar o material que Villa-Lobos tinha a sua disposição para desenvolver a obra. Todas estas possibilidades contrapontísticas apontam para um entendimento contrapontístico e representam uma afinidade bachiana, uma alusão à linguagem de Bach, uma releitura bastante sofisticada de procedimentos técnicos observados e utilizados por Bach (vide Exemplo 12b-d).

\section{Exemplo 12a}

152

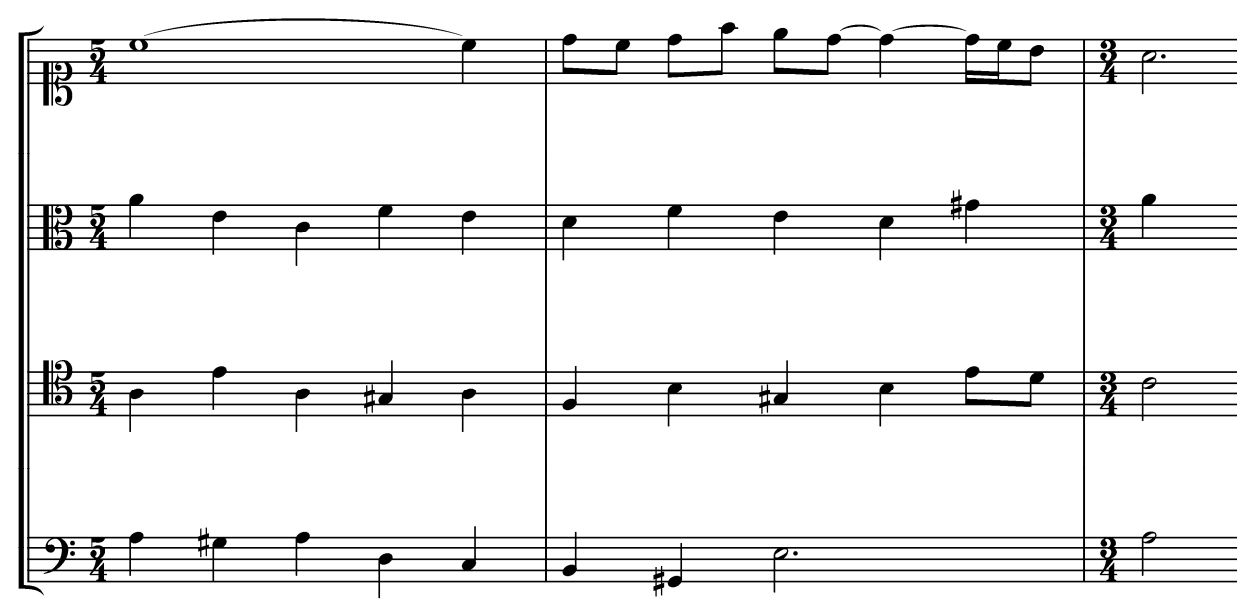

\section{Exemplo 12b}

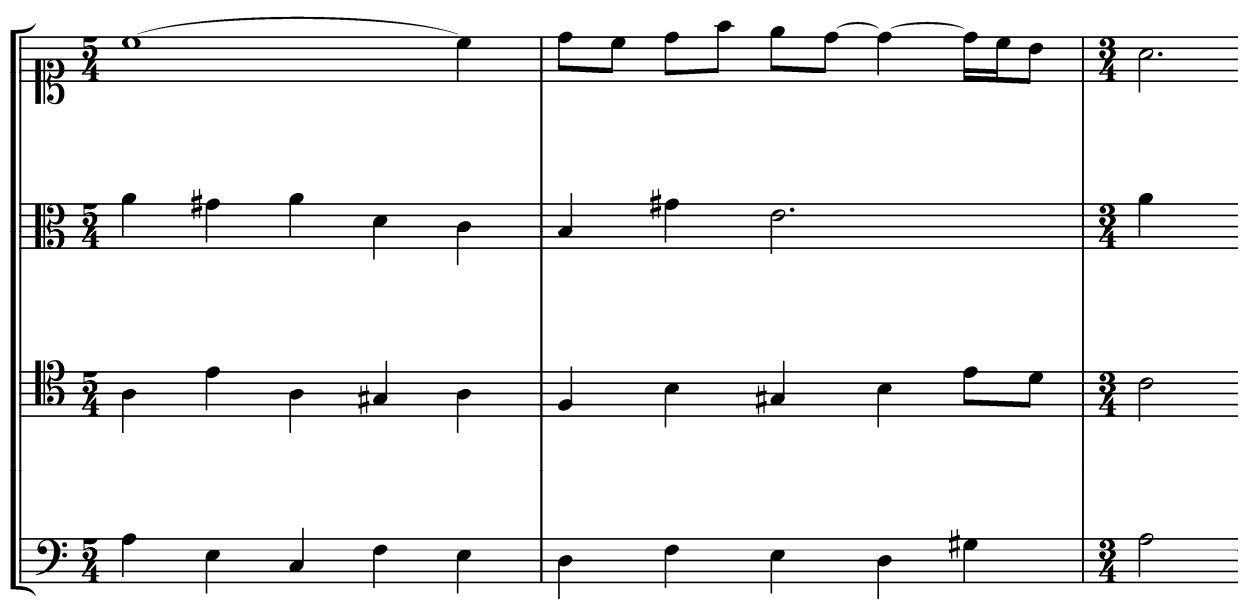




\section{Exemplo 12c}

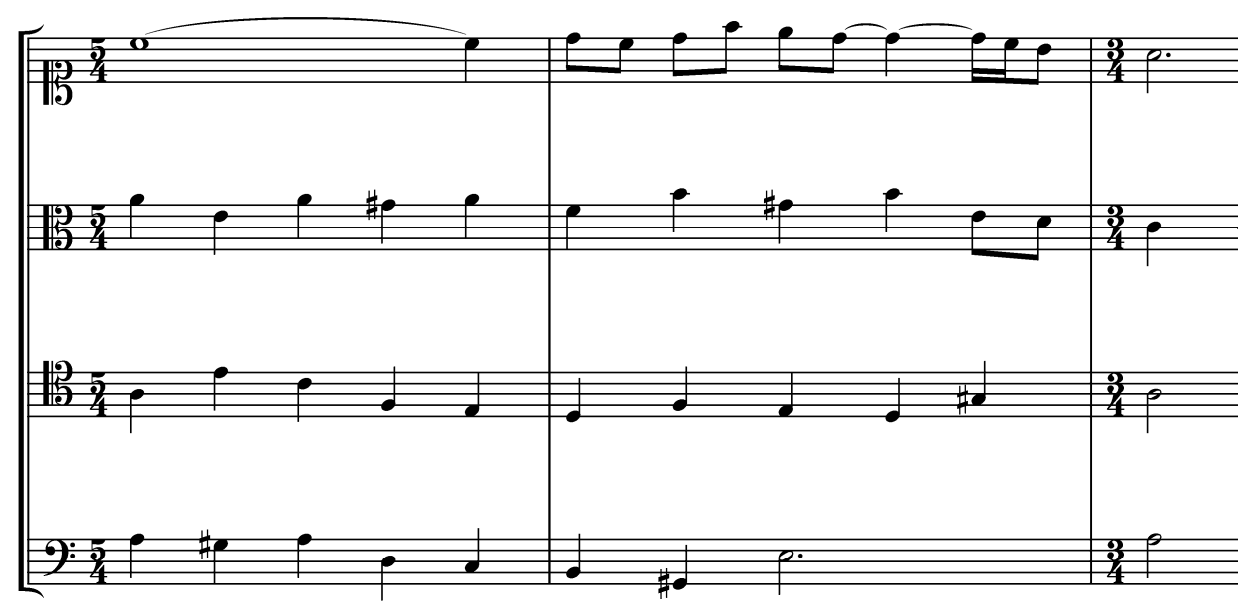

\section{Exemplo 12d}

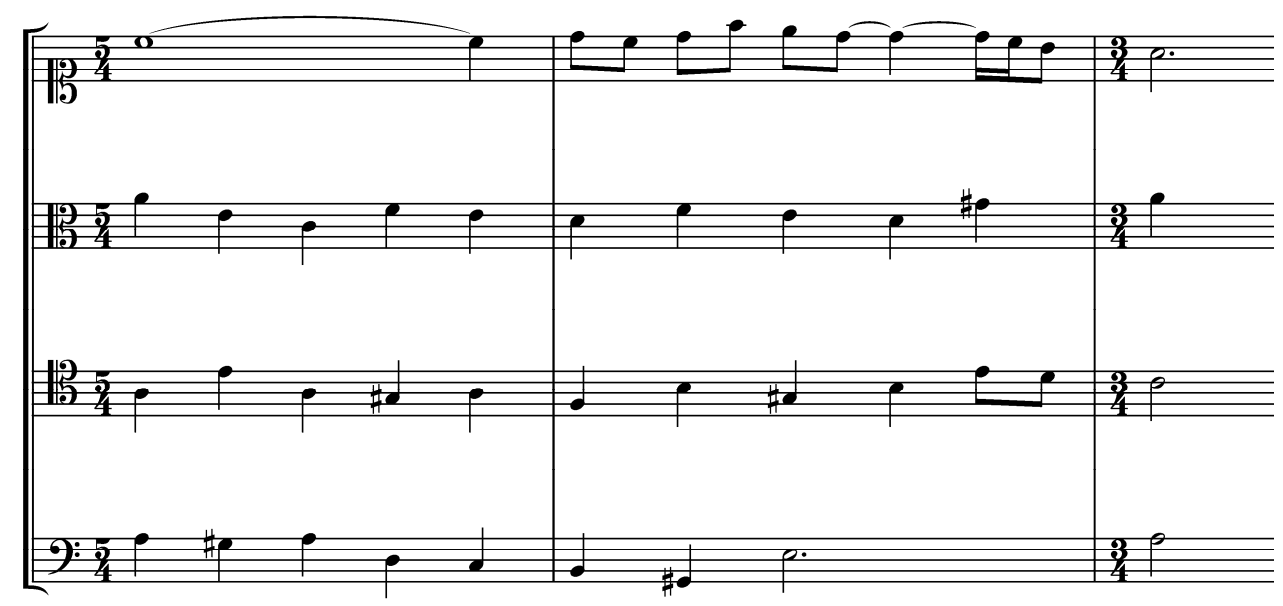

Finalmente, as referências à música popular brasileira que Villa-Lobos tenta inserir nas suas Bachianas podem ser observadas nos movimentos lentos das Bachianas, os quais, por vezes, sofrem a designação de Ária ou, mais especificamente, Modinha (Bachianas n. 3, $3^{\circ}$ movimento), Cantiga (Bachianas $n$. 4, $3^{\circ}$ movimento), e Cantilena, caso da presente obra. Uma possível aproximação entre a Cantilena e a música popular talvez seja o caráter modinheiro e seresteiro conferido à obra. Melodias longas e lânguidas, acompanhamento em acordes repetidos e sincopados com fragmentos escalares são características bastante 
vagas, mas que de certa maneira se aplicam ao arranjo realizado pelo compositor da Cantilena para voz e acompanhamento de violão. Estas figurações se aproximam de acompanhamentos de canções, cançonetas, modinhas, choroscanção e serestas. Ilustrativo deste aspecto relacionado à música popular brasileira é o fragmento mostrado no Exemplo 13 do arranjo do compositor para voz e violão.

\section{Exemplo 13}

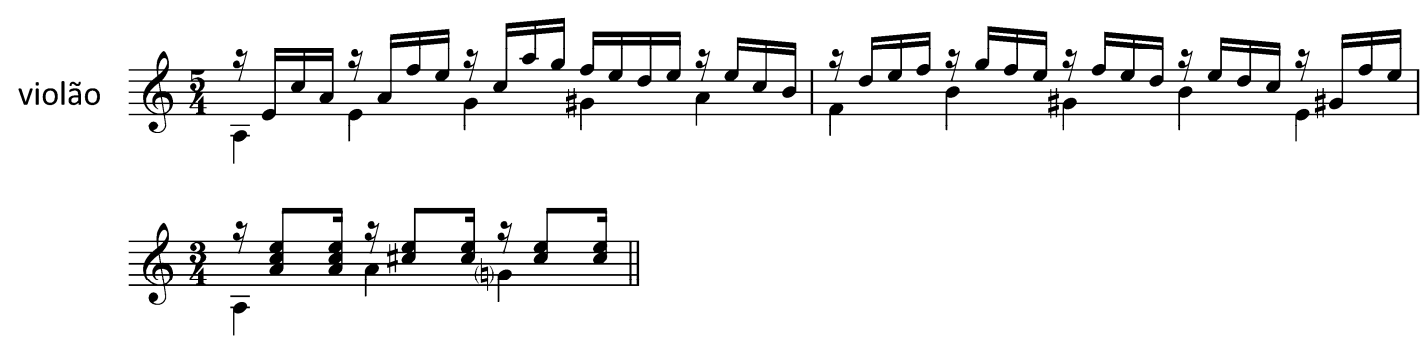

\section{Conclusão}

Se por um lado Villa-Lobos mitifica a figura de Bach como uma "fonte folclórica universal" de alto valor estético e até mesmo educacional, por outro Villa-Lobos argumenta por uma restauração de Bach, mesmo que tardiamente, bem adentro do século XX. Poder-se-ia argumentar que as Bachianas Brasileiras pertencem à corrente do neoclassicismo surgida durante os anos 1920-1930, na Europa continental, mas a releitura que Villa-Lobos propõe nas suas obras parece ir um pouco além desta simples classificação dentro de uma tendência. Ela parece ser, de fato, uma restauração de uma figura mítica, super-humana através da incorporação de elementos estilísticos reinterpretados dentro do contexto artístico, musical, educacional e político brasileiros. Talvez uma das avaliações mais concisas das Bachianas Brasileiras a este respeito seja a de Wright (1992) que argumenta que esta série de obras deve ser vista não somente à luz de elementos estilísticos bachianos, mas sim em relação ao seu etos, às características de sua 
época, ao espírito da sua era - a era de Vargas, ou a era de abrasileirar tudo que não fosse brasileiro, inclusive a música européia de Bach (p. 78-106).

A série de Bachianas Brasileiras composta por Villa-Lobos é a obra mais significativa que faz alusões e referências à música de Bach na música latinoamericana do século XX. A Cantilena da Bachianas n. 5 ilustra estas afinidades de maneira notável. Em particular, a melodia com o desdobramento do material motívico tem semelhança à técnica freqüentemente observada na música de Bach.

Ainda, Villa-Lobos reconhece sua herança da música do passado, e percebe sua música como uma evolução daquela música; no entanto, ele advoga por uma música sensível e expressiva. Ele declara (1969, p. 120):

Sinto e compreendo o século XX, como de um progresso amadurecido das artes dos séculos passados, mas não música como prenúncio de uma arte tão mecânica que transforme a sensibilidade humana num aparêlho [sic] de rádio.

A Cantilena demonstra esta visão muito bem, é uma obra imbuída de alto teor expressivo, técnico e artístico, e de referencial histórico.

\section{Referências}

ALMEIDA, Renato. História da Música Brasileira. Rio de Janeiro: F. Briguiet, 1942.

APPLEBY, David. The Music of Brazil. Austin: University of Texas Press, 1983.

ARCANJO JR., Loque. O ritmo da mistura e o compasso da História: O Modernismo musical nas Bachianas Brasileiras de Heitor Villa-Lobos. Dissertação de mestrado - Departamento de História da UFMG, 2007. p. 55-102.

AZEVEDO, Luiz Heitor Corrêa de. Brief History of Music in Brazil. Washington: Division of Music and Visual Arts, 1948.

BÉHAGUE, G. Heitor Villa-Lobos: The Search for Brazil's Musical Soul. Austin: Institute of Latin American Studies, 1994.

Music in Latin America: An Introduction. Englewood Cliffs, N.J.: Prentice Hall, 1979.

BEKKER, Paul. Neue Musik. Stuttgart: Deustche Videlags-Anstalt, 1923. 
BESSELER, Heinrich. Grundfragen des musikalischen Hörens. Jahrbuch der Musikbibliothek Peters für 1925, Leipzig, p. 35-52, 1926.

BLUME, Friederich. Bach in the Romantic Era. The Musical Quarterly, v. 50, n. 3, p. 290306, 1964.

CORRÊA, Sérgio Nepomuceno Alvim. Leopoldo Miguéz, Catálogo de Obras. Rio de Janeiro: Academia Brasileira de Música, 2005.

Alberto Nepomuceno. Catálogo Geral. Rio de Janeiro: Funarte, 1985.

DAHLHAUS, Carl. Foundations of Music History. Tradução para o inglês: J. B. Robinson. Cambridge: Cambridge University Press, 1983.

FINSCHER, L. Bach's Posthumous Role in Music History. In: MARISSEN, Michael (Ed.). Bach Perspectives 3. Lincoln: University of Nebraska Press, 1998. p. 1-21.

FRISCH, Walter. Reger's Bach and Historicist Modernism. 19th-Century Music, v. 25, n. 2/3, p. 296-312, 2001.

HEITOR, Luiz. 150 Anos de Música no Brasil (1800-1950). Rio de Janeiro: José Olympio Editora, 1956.

HINDEMITH, Paul. The Craft of Musical Composition, Book 1: Theory. Tradução para o inglês: Arthur Mendel. New York: Schott Music Corporation, 1942.

HINTON, Stephen. Hindemith, Bach, and the Melancholy of Obligation. In: MARISSEN, Michael (Ed.). Bach Perspectives 3. Lincoln: University of Nebraska Press, 1998. p. 133-150.

KIEFER, Bruno. Villa-Lobos e o modernismo na música brasileira. Porto Alegre: Movimento, 1986.

KINDERMANN, William. Bachian Affinities in Beethoven. In: MARISSEN, Michael (Ed.). Bach Perspectives 3. Lincoln: University of Nebraska Press, 1998. p. 81-108.

LORENZEN, Johannes. Max Reger als Bearabeiter Bachs. Wiesbaden: Breitkopf und Härtel, 1982.

NÓBREGA, Adhemar. As Bachianas Brasileiras de Villa-Lobos. 2. ed. Rio de Janeiro: MEC Departamento de Assuntos Culturais, 1976.

Atualidade da Música de Villa-Lobos. In: Presença de Villa-Lobos. Rio de Janeiro: MEC-Museu Villa-Lobos, 1969. p. 13-19.

PRESENÇA de Villa-Lobos. Rio de Janeiro: MEC - Museu Villa-Lobos, 1969.

SCHOENBERG, Arnold. The Musical Idea. New York: Columbia University Press, 1995. Style and Idea. London: Faber and Faber, 1975.

TARUSKIN, Richard. Stravinsky and the Russian Traditions. Oxford: Oxford University Press, 1996.

VILLA-LOBOS, Heitor. Minha Filosofia. In: Presença de Villa-Lobos. Rio de Janeiro: MEC Museu Villa-Lobos, 1969. p. 119-120. 
VILLA-LOBOS. SUA OBRA. Catálogo. Rio de Janeiro: MEC - Museu Villa-Lobos, 1972.

WISNIK, José Miguel. O orfeão do Estado Novo/Esse coqueiro que dá coco. In: SQUEFF, E; WISNIK, José Miguel. O Nacional e o Popular na Cultura Brasileira. São Paulo: Brasiliense, 2001. p. 178-190.

WRIGHT, Simon. Villa-Lobos. Oxford: Oxford University Press, 1992.

Norton Dudeque: nortondudeque@gmail.com

Artigo recebido e aprovado em: 20 de setembro de 2008 